\title{
Application of Time Domain Electromagnetic (Tdem) Methods for Mapping of Salt Fresh Water Intrusions and Evaluate The Porosity in Carbyn's Cove, Wandoor and Khurumedhera Beaches in South Andaman
}

\author{
Vignesh A*, Ramanujam N, Swapan Kumar B and Rasool QA
}

Department of Disaster Management, Pondicherry University, Port blair - 744112, Andaman Islands, India

\begin{abstract}
Time Domain Electromagnetic (TDEM) methods are successfully used to delineate the geometry of different hydrogeological targets to determine porosity of saline and freshwater zones. TDEM can be used to determine both fluid resistivities ( $\rho w)$ and bulk resistivities $(\rho)$ which are required to calculate the porosity by applying Archie's equation. By studying saline water intrusion near coastal zone, where $\rho w$ and $\rho$ can be determined very accurately by applying TDEM method. From the literature review, it is revealed that the TDEM method is the most suitable geophysical technique for seawater intrusion. TDEM technique is very sensitive to high conductive (low resistivity) zones hence this technique can be applied to study the saltwater intrusion into the fresh water aquifers. Therefore, the aim of the presence study is to find out the porosity of saline water zone for the EM data generated with TDEM technique in the areas of Carbyn's Cove, Khurumedhera and Wandoor beach of South Andaman The TDEM images shows the range of interface between saline water and fresh water at depth of 4-10 m from the shoreline to distance of $20 \mathrm{~m}$ in Carbyns cove beach, $7-18 \mathrm{~m}$ from $10 \mathrm{~m}$ distance in Wandoor beach and $11-17 \mathrm{~m}$ from $30 \mathrm{~m}$ in Khurumedhera beach, indicating the varying amount of mixing of sea-water throughout the aquifer. The porosity of saltwater and freshwater shows that the low porosity indicates high salinity corresponds to salty brackish water with porous/ sandy or saturated clay and high porosity indicates low salinity corresponds to intermediate quality fresh water zone with Sand/gravel or minor clay. It is reasonably presumed from present field study, a close correspondence between the high resistivity zones that encompass with lower total dissolved solids concentration (fresh water) and lower resistivity region was incorporated with the higher amount of total dissolved solids concentration. TDEM soundings with Central Loop Technique appear to be a suitable tool to demarcate the transition zones between fresh water and salt water.
\end{abstract}

Keywords: Time Domain Electromagnetic (TDEM) method; Salt water intrusion; Porosity; Salinity; Andaman

\section{Introduction}

Time Domain Electromagnetic (TDEM) method is applied delineate the salt and freshwater interface along the shoreline to study seawater intrusion. In this technique a close connection between electrical conductivity/ resistivity and salt and fresh water salinity can be visualised. Many of the geophysical methods were focused to study the distribution of seawater intrusion, the depth to fresh - saline groundwater interface, etc. A variety of geophysical methods has been adopted in saltwater intrusion investigations. Conventional DC resistivity techniques have been used very long time to characterize shallow aquifers whereas the gravity and magnetic approaches were applied to reconstruct deep aquifers and the bedrock. Other applications have involved electromagnetic and seismic methods.

The TEM sounding is a proven successful and powerful technique for mapping of interfaces between fresh water and salt water, in which the electrical resistivity of the subsurface layers to several hundred meters of depth can be measured by increasing time duration [1].

We calculated the parameters needed for Archie's law from the TEM Section as: The theoretical basis for such investigations is being constituted by the empirical Archie's equation [2]:

$$
\mathrm{rw} / \mathrm{r}=\mathrm{aFm}
$$

Where $\mathrm{rw}$ is the resistivity of water within the pore space, $r$ is the bulk resistivity of the rock, $\mathrm{F}$ is the porosity of the rock (approximately representing the volume of water filling the pore space), a and $\mathrm{m}$ are material-dependent empirical factors, which are introduced to force the equation to fit the behavior of a rock in question. Since $m$ increases with cementation, [2] named it cementation index, having the characteristic value of 1.3 for unconsolidated sands and varying between 1.8 and 2 for consolidated sandstones.

The detailed description of the method is given in numerous publications, including those devoted to groundwater exploration [3]. The present paper discusses only those features of the method that are relevant to the determination of the porosity of the aquifer. With empirical Archie's equation the relationship between porosity and salinity can be established $[2,3]$.

$$
\frac{\rho_{w}}{\rho}=\Phi^{2} \text {. }
$$

Where $\rho_{\mathrm{w}}$ is the resistivity of water (From the TDS value, Conductivity of Water, we can calculate the Resistivity of water), $\rho$ is the bulk resistivity of the rock, $\phi$ is the porosity of the rock.

\section{Geological settings of study area}

${ }^{*}$ Corresponding author: Dr. Vignesh A, Department of Disaster Management, Pondicherry University, Port blair - 744112, Andaman Islands, India, TEL: 0413 2655179 E-mail: vignesh@live.com.sg

Received September 18 2015; Accepted September 25 2015; Published October 022015

Citation: Vignesh A, Ramanujam N, Kumar BS, Rasool QA (2015) Application of Time Domain Electromagnetic (Tdem) Methods for Mapping of Salt Fresh Water Intrusions and Evaluate The Porosity in Carbyn's Cove, Wandoor and Khurumedhera Beaches in South Andaman. J Coast Zone Manag 18: 413. doi: 10.4172/2473-3350.1000413

Copyright: (C) 2015 Vignesh A, et al. This is an open-access article distributed under the terms of the Creative Commons Attribution License, which permits unrestricted use, distribution, and reproduction in any medium, provided the original author and source are credited. 
Citation: Vignesh A, Ramanujam N, Kumar BS, Rasool QA (2015) Application of Time Domain Electromagnetic (Tdem) Methods for Mapping of Salt Fresh Water Intrusions and Evaluate The Porosity in Carbyn's Cove, Wandoor and Khurumedhera Beaches in South Andaman. J Coast Zone Manag 18: 413. doi: 10.4172/2473-3350.1000413

The Carbyn's Cove ( $\left.11^{\circ} 38^{\prime} 36.353^{\prime \prime} \mathrm{N}, 92^{\circ} 44^{\prime} 48.798^{\prime \prime} \mathrm{E}\right)$ beach is located in the East coast of South Andaman bounded between the Port Blair Formation in North and West and Ophiolite suite exposed in the Brookshabad regions on South. On the Southern side fault controlled tidal mangrove creeks confluences with Andaman Sea in the East. The exposures of beach sediments upto 50 to $60 \mathrm{~m}$ from the shoreline beyond that muddy, silt sediments derived from Port Blair Formation are extended upto $500 \mathrm{~m}$ length. Carbyn's Cove is formed as graben structure between the two fault lines on South and North. The length of the beach in North - South trend is about $300 \mathrm{~m}$. The constitution of the Carbyn's cove sediments are mangrove soil, loose sand, shaly limestone and shaly conglomerate [4-6] (Figure 1).

The Wandoor ( $\left.11^{\circ} 37^{\prime} 12.66^{\prime \prime} \mathrm{N}, 92^{\circ} 37^{\prime} 2.717^{\prime \prime} \mathrm{E}\right)$ and Khurumedhera $\left(11^{\circ} 39^{\prime} 58.086^{\prime \prime} \mathrm{N}, 92^{\circ} 35^{\prime} 42.024^{\prime \prime} \mathrm{E}\right)$ beaches are located along the Bay of Bengal. These beaches are bounded with Port Blair Formation in all direction except Western part. The study areas are geographically plain in nature and developed between the faults controlled by cliffs. Sediments are assemblages at Wandoor and Khurumedhera are of sandstone, siltstone and shale (Figure 1).

The tectonic disequilibrium has direct impact on the development of geomorphic, hydrodynamic and sedimentary environment in this part of the study area. The low gradient of the submerged landmass after 2004 Earthquake is a paved way for sea water intrusion in coastal aquifers of prime agricultural land has increased soil salinity.

\section{Methodology}

The saltwater intrusion was studied by the geophysical techniques such as Resistivity, Induced Polarization, and Electromagnetic method. In the study area we carried out Electromagnetic Method using Central loop configurations with conductivity values.

\section{Field procedures}

Figure 2 shows a typical layout for a "Central loop" TDEM sounding. Field procedures involve placing a square loop of wire (typically $10 \times 10$ $\mathrm{m}^{2}, 20 \times 20 \mathrm{~m}^{2}$ and $30 \times 30 \mathrm{~m}^{2}$ ) on the ground surface and measurements

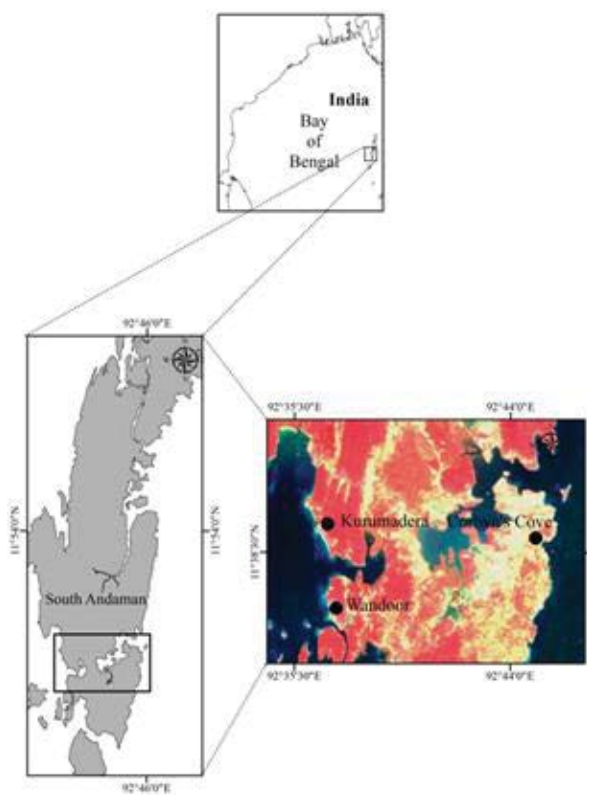

Figure 1: Location map of Study Area. are made with a small receiver coil (typically $3 \times 3 \mathrm{~m}^{2}, 9 \times 9 \mathrm{~m}^{2}$ and $15 \times 15 \mathrm{~m}^{2}$ ) in the centre of the transmitter loop (Figures 3-5), as the induced electric current penetrate and diffuse through the earth. The investigation depth depends on the characteristics of the transmission and of the subsurface. The main advantages of this method are the good ratio of the penetration depth over the space required by the layout, and a high sensitivity to the well-conducting soil layers. The main disadvantages are a rather poor resolution obtained for the resistive layers as well as for the near surface layers.

TDEM measurements were carried out to detect saline water bodies within different aquifers and to delineate the interface between these saline bodies and the fresh ones. In order to quantitatively evaluate the ability of the TDEM method to both delineate geometrical features of seawater intrusion and characterize groundwater salinity, almost three TDEM measurements were performed.
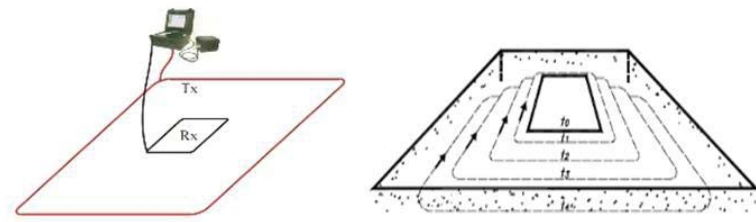

Figure 2: Setup method of Central Loop Configuration.

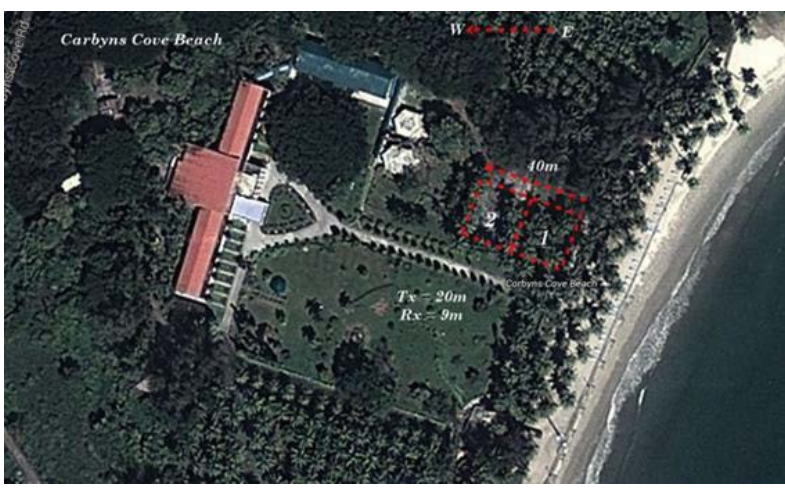

Figure 3: Loop configurations and direction of survey in the Carbyn's Cove.

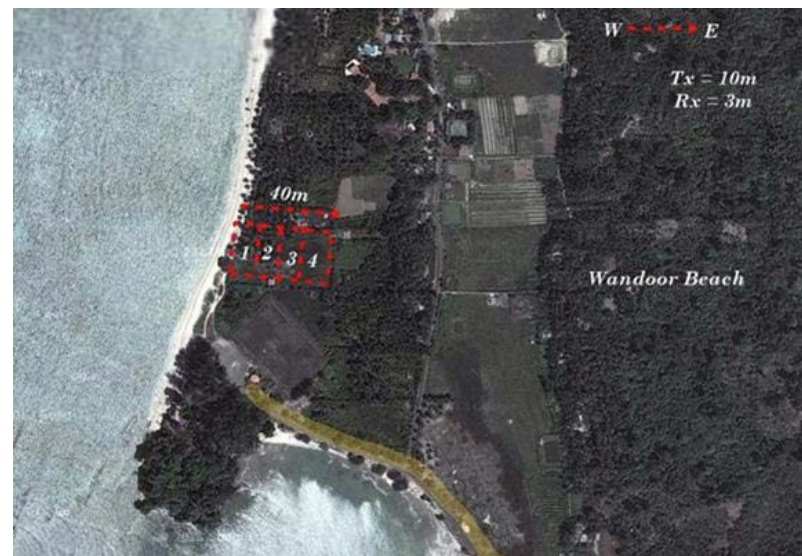

Figure 4: Loop configurations and direction of survey in the Wandoor. 
Citation: Vignesh A, Ramanujam N, Kumar BS, Rasool QA (2015) Application of Time Domain Electromagnetic (Tdem) Methods for Mapping of Salt Fresh Water Intrusions and Evaluate The Porosity in Carbyn's Cove, Wandoor and Khurumedhera Beaches in South Andaman. J Coast Zone Manag 18: 413. doi: 10.4172/2473-3350.1000413

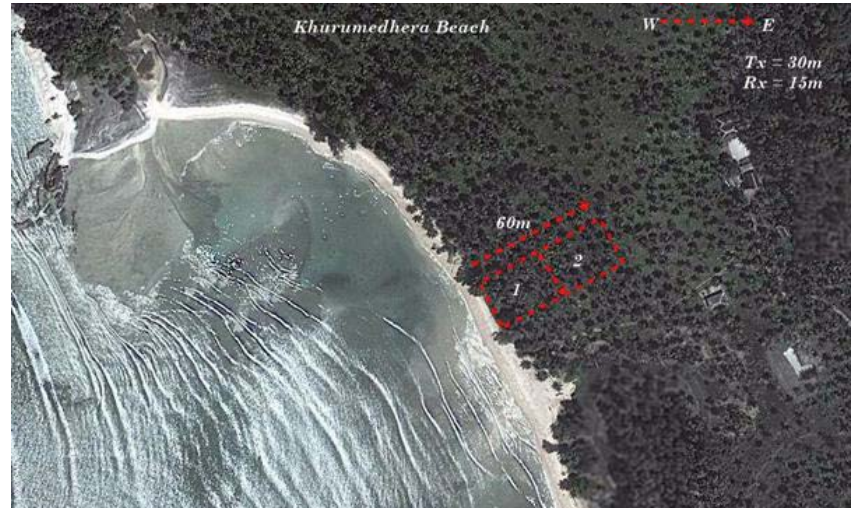

Figure 5: Loop configurations and direction of survey in the Khurumedhera Resistivity - salinity calibration.

\begin{tabular}{|c|c|c|c|c|c|}
\hline- & $\phi$ & $\stackrel{\rho_{w}}{(O h m-m)}$ & $\begin{array}{c}\rho \\
(O h m-m)\end{array}$ & $\begin{array}{l}\text { Salinity } \\
\text { (mg/l) }\end{array}$ & $\begin{array}{l}\text { Sediment } \\
\text { Rock }\end{array}$ \\
\hline Carbyn cove & 0.12 & 2.8 & 177.4 & 2499.9 & Salty Brackish \\
\hline Wandoor & 0.03 & 0.9 & 657.2 & 7446.7 & Salty Brackish \\
\hline Khurumedhera & 0.04 & 1.2 & 570.35 & 5833.3 & Salty Brackish \\
\hline
\end{tabular}

Table 1: Salinity calculation at Salted water zone.

\begin{tabular}{|c|c|c|c|c|c|}
\hline- & $\phi$ & $\begin{array}{c}\rho_{w} \\
(O h m-m)\end{array}$ & $\begin{array}{c}\rho \\
(\mathrm{Ohm}-\mathrm{m})\end{array}$ & $\begin{array}{l}\text { Salinity } \\
\text { (mg/l) }\end{array}$ & $\begin{array}{l}\text { Sediment } \\
\text { Rock }\end{array}$ \\
\hline Carbyn cove & 0.46 & 37.9 & 177.4 & 184.6 & $\begin{array}{c}\text { Intermediate } \\
\text { quality Freshwater }\end{array}$ \\
\hline Wandoor & 0.25 & 41.91 & 657.2 & 167.0 & $\begin{array}{c}\text { Intermediate } \\
\text { quality Freshwater }\end{array}$ \\
\hline Khurumedhera & 0.25 & 35.83 & 570.35 & 195.3 & $\begin{array}{c}\text { Intermediate } \\
\text { quality Freshwater }\end{array}$ \\
\hline
\end{tabular}

Table 2: Salinity calculation at freshwater Zone.

The attempts to characterize groundwater salinity in the salinity ranges typical for fresh and brackish water using the interpreted TDEM resistivities. Tables 1 and 2 shows that the ability of TDEM to quantitatively characterize salt - groundwater - salinity. Indeed, if the salinity exceeds $10,000 \mathrm{mg} / \mathrm{l}$ (Saline water). The resistivity characterizing the brackish water salinity range $(1,000$ to $10,000 \mathrm{mg} / \mathrm{l})$ vary in the range, between 0.9 to $2.8 \Omega \mathrm{m}$ and the freshwater salinities (below $1000 \mathrm{mg} / \mathrm{l}$ ) are characterized by resistivity range between 35.83 to $41.91 \Omega \mathrm{m}[1]$

\section{Porosity calculations}

Based on the fact that resistivity below $10 \mathrm{ohm}-\mathrm{m}$ is uniquely indicative of seawater intrusion into the coastal aquifer [7-10].

\section{Results and Discussion}

\section{Carbyn cove beach}

The location of seawater / freshwater interface at the depth of approximately $6 \mathrm{~m}$. The shallow sequence from the surface to the depth of $16 \mathrm{~m}$ exhibits high resistivities representing the underlying freshwater saturated aquifer. The thickness of the unsaturated zone at this site is only $4 \mathrm{~m}$. The intermediate zone between 6 and $16 \mathrm{~m}$ exhibits resistivity values for aquifers saturated with brackish waters, salinity may vary in a wide range.

Profiles from the sea to landward direction exhibits the distribution pattern of hosted brines with the resistivity values $0.024-0.41 \mathrm{ohm}-\mathrm{m}$ and normal sea water concentrations shows as the resistivity values of $1.51-9.46 \mathrm{ohm}-\mathrm{m}$. The fresh water aquifer with high resistivity values $16.3-59.5 \mathrm{ohm}-\mathrm{m}$ and the resistivity values for sand and gravel ranges upto $370.3 \Omega \mathrm{m}$ (Figure 6).

The very low resistivity layer reflects seawater intrusion. Applying equation (1), the porosity of the seawater (Study Area) was calculated for the intruded portion of the aquifer by using TDEM data. Thus the calculated porosity is $\phi=0.12$ and salinity $=2499.9 \mathrm{mg} / \mathrm{l}$.

The shallow resistivity sequence, the porosity calculations of the fresh water in the area is $\phi=0.46$. Some additional semi - quantitative information can be also obtained regarding the groundwater salinity within the intermediate resistivity zone. This resistivity range corresponds to salinities $184.6 \mathrm{mg} / \mathrm{l}$.

\section{Wandoor beach}

The location of seawater / freshwater interface at the depth of approximately $11 \mathrm{~m}$. The shallow sequence from the surface to the depth of $39 \mathrm{~m}$ exhibits high resistivities representing the underlying freshwater saturated aquifer. The thickness of the unsaturated zone at this site is only $3 \mathrm{~m}$. The intermediate zone between 11 and $39 \mathrm{~m}$ exhibits resistivity values for aquifers saturated with brackish waters, salinity may vary in a wide range.

Profiles from the sea to landward direction exhibits the distribution pattern of hosted brines with the resistivity values $0.05-0.10 \mathrm{ohm}-\mathrm{m}$ and normal sea water concentrations shows as the resistivity values of $1.25-2.39 \mathrm{ohm}-\mathrm{m}$. The fresh water aquifer with high resistivity values $28.73-55.09 \mathrm{ohm}-\mathrm{m}$ and the resistivity values for sand and gravel ranges upto $10,000 \Omega \mathrm{m}$ (Figure 7).

The calculated porosity is $\phi=0.03$ and salinity $=7446.7 \mathrm{mg} / \mathrm{l}$. The shallow resistivity sequence, the porosity calculations of the fresh water in the area is $\phi=0.25$. Some additional semi - quantitative information can be also obtained regarding the groundwater salinity within the intermediate resistivity zone. This resistivity range corresponds to salinities $167.0 \mathrm{mg} / \mathrm{l}$.

\section{Khurumedhera beach}

The location of seawater / freshwater interface at the depth of approximately $7 \mathrm{~m}$. The shallow sequence from the surface to the depth of $14 \mathrm{~m}$ exhibits high resistivities representing the underlying freshwater saturated aquifer. The thickness of the unsaturated zone at this site is only $3 \mathrm{~m}$. The intermediate zone between 7 and $14 \mathrm{~m}$ exhibits resistivity values for aquifers saturated with brackish waters, salinity may vary in

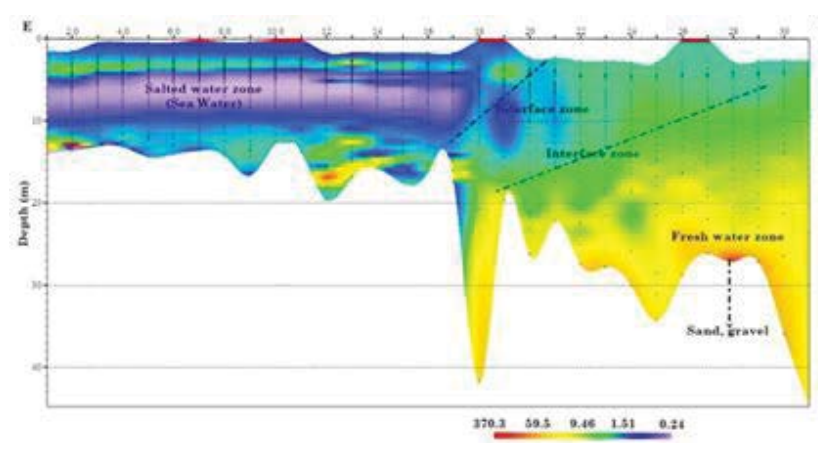

Figure 6: Fresh water aquifer in between the saline water aquifer in Carbyns cove beach. The low TDEM resistivities between 4 to $10 \mathrm{~m}$ depth are in agreement with the high groundwater salinity. 
Citation: Vignesh A, Ramanujam N, Kumar BS, Rasool QA (2015) Application of Time Domain Electromagnetic (Tdem) Methods for Mapping of Salt Fresh Water Intrusions and Evaluate The Porosity in Carbyn's Cove, Wandoor and Khurumedhera Beaches in South Andaman. J Coast Zone Manag 18: 413. doi: 10.4172/2473-3350.1000413

a wide range.

Profiles from the sea to landward direction exhibits the distribution pattern of hosted brines with the resistivity values $0.09-0.185 \mathrm{ohm}-\mathrm{m}$ and normal sea water concentrations shows as the resistivity values of $1.57-2.96 \mathrm{ohm}-\mathrm{m}$. The fresh water aquifer with high resistivity values $25.12-46.51 \mathrm{ohm}-\mathrm{m}$ and the resistivity values for sand and gravel ranges upto $5000 \Omega \mathrm{m}$ (Figure 8).

The calculated porosity is $\phi=0.04$ and salinity $=5833 \mathrm{mg} / \mathrm{l}$. The shallow resistivity sequence, the porosity calculations of the fresh water in the area is $\phi=0.25$. Some additional semi - quantitative information can be also obtained regarding the groundwater salinity within the intermediate resistivity zone. This resistivity range corresponds to salinities $195.3 \mathrm{mg} / \mathrm{l}$.

\section{Conclusion}

TDEM resistivity measurements allow accurate detection of the geometry and bulk resistivity of seawater intrusion into granular and carbonate coastal aquifers. This, in turn, facilitates more accurate estimation of porosity of seawater intruded parts of the aquifers, since both the bulk and the fluid resistivities are accurately determined in these parts. The obtained porosity, in most cases, adequately represents the entire aquifer or its major parts, since it is generally similar both above and below the freshwater/seawater interface.

Experience shows that the most suitable geophysical technique for the exploration of saline groundwater is the time domain electromagnetic (TDEM) method. Numerous measurements carried

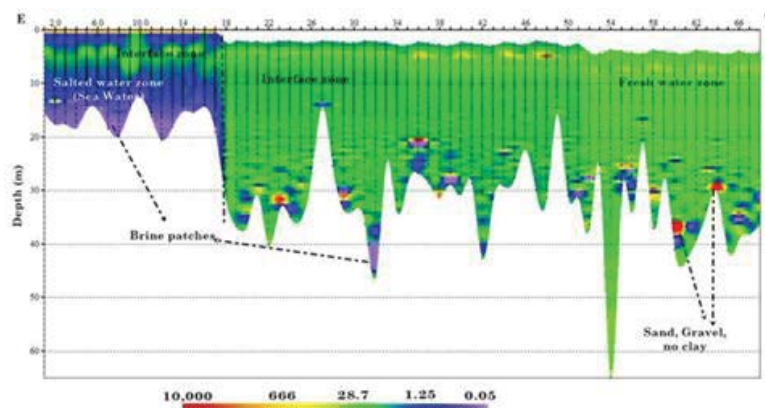

Figure 7: Fresh water aquifer in between the saline water aquifer in Wandoor Beach. The low TDEM resistivities between 7 to $18 \mathrm{~m}$ depth are in agreement with the high groundwater salinity.

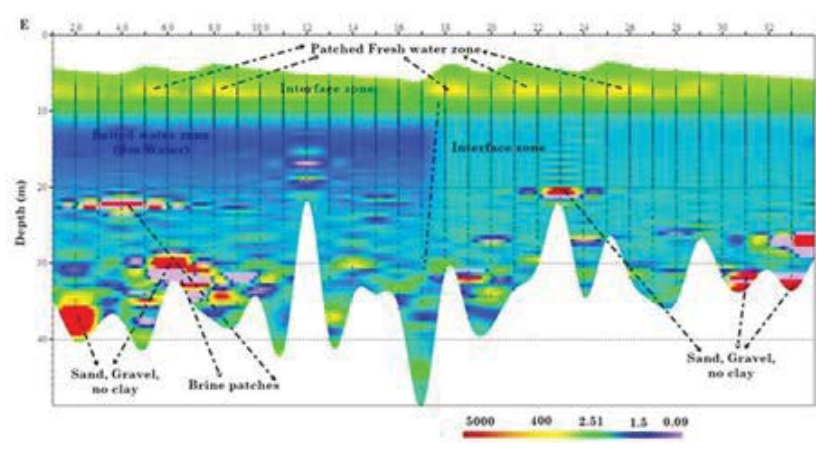

Figure 8: Fresh water aquifer in between the saline water aquifer in Khurumedhera Beach. The low TDEM resistivities between 11 to $17 \mathrm{~m}$ depth are in agreement with the high groundwater salinity. out in different granular clastic aquifers have proven that the bulk resistivity of saline water saturated portion of the aquifer is accurately detected by TDEM without any use of a priory information. Therefore, under favourable conditions, the porosity of the saline water saturated portion of the aquifer can be also accurately determined from the Archie's equation by using only geophysical data. The obtained porosity might be projected then to the freshwater saturated portion of the aquifer since it is reasonable to assume that hydraulic properties of the aquifer are essentially the same both below and above the freshwater/ seawater interface.

Pattern of salt water distribution indicates that salt water intrusion into the fresh water zone from shoreline to adjoining lands. The TDEM images shows the range of interface between saline water and fresh water at depth of $4-10 \mathrm{~m}$ from the shoreline to distance of $20 \mathrm{~m}$ in Carbyns cove beach, $7-18 \mathrm{~m}$ from $10 \mathrm{~m}$ distance in Wandoor beach and $11-17 \mathrm{~m}$ from $30 \mathrm{~m}$ in Khurumedhera beach. This suggest that the varying values of conductivity are indicating the varying amount of mixing of seawater throughout the aquifer. The porosity of saltwater and freshwater shows that the low porosity indicates high salinity corresponds to salty brackish water with porous/ sandy or saturated clay and high porosity indicates low salinity corresponds to intermediate quality fresh water zone with Sand/gravel or minor clay. TDEM facilitates the porosity of seawater intruded parts and fresh water zones.

Some aspects affecting the resistivity values of a rock can be describing as follows [11]:

- Rocks are resulted from loose sedimentation show a low resistivity value when compared to compact rocks.

- Igneous and metamorphic rocks (dry rocks) having a high value in Wandoor (10000) and Khurumedhera (5000) areas.

- Wet rocks containing a lot of water and having a low resistivity value show very low values when found in wet lands with salt water.

- Mineral content in the surrounding area of a pack of rock influences the resistivity value of that rock.

\section{Acknowledgement}

We thank and acknowledge the facilities and permission accorded by the Vice chancellor of Pondicherry University Prof Chandra Krishnamurthy, Director Dean and Registrar for constant encouragement and support. Our gratitude is also addressed to our colleagues that we cannot mention one by one.

\section{References}

1. Archie G (1942) The Electrical Resistivity Log as an Aid in Determining Some Reservoir Characteristics. Transactions of the American Institute of Mining and Metallurgical Engineers 146.

2. Bernard J (2003) Short note on the principles of geophysical methods for groundwater investigations. Terraplus.

3. Eddy Ibrahim (2008) International Journal of Science Engineering and Technology 3: 55-59.

4. Fitterman DV, Stewart MT (1986) Transient Electromagnetic Soundings for Groundwater. Geophysics 51: 995-1005.

5. Goldman M, Gilad D, Ronen A, Melloul A (1991) Mapping of seawater intrusion into coastal aquifer of Israel by the time domain electromagnetic method. Geoexploration 28: 153-174

6. Goldman M, Kafri U, Yeachieli Y (2003) Application of the Time Domain Electromagnetic (TDEM) method for studying groundwater salinity in different coastal aquifers of Israel. In: Lopez-Geta JA, de Dios Gomes J, de la Orden JA, Ramos, Rodriguez L (Editors) Coastal aquifers intrusion technology: Mediterranean countries. The Institute of Geology and Mineralogy of Spain (IGME): 45-56. 
Citation: Vignesh A, Ramanujam N, Kumar BS, Rasool QA (2015) Application of Time Domain Electromagnetic (Tdem) Methods for Mapping of Salt Fresh Water Intrusions and Evaluate The Porosity in Carbyn's Cove, Wandoor and Khurumedhera Beaches in South Andaman. J Coast Zone Manag 18: 413. doi: 10.4172/2473-3350.1000413

Page 5 of 5

7. Goldman M, Kafri U (2004) The use of the time domain electromagnetic (TDEM) method to evaluate porosity of saline water saturated aquifers. 18 SWIM. Cartagena, Spain. (Editors). Araguas, Custodio and Manzano). IGME

8. Jafri SH, Balaram V, Ramesh SL (1990) Geochemistry of Andaman-Nicoba island basalts: A case for a possible plume origin. Journal of Volcanology and Geothermal Research 44: 339-347.

9. Pal T, Chakraborty PP, Gupta TD, Singh CD (2003) Geodynamic evolution of the outer-arc-forearc belt in the Andaman Islands, the central part of the
Burma-Java subduction complex. Geological Magazine 140: 289-307.

10. Roy TK (1983) Geology and hydrocarbon prospects of Andaman-Nicobar basin, in Bhandari, L.L., ed., Petroliferous Basins of India: Petroleum Asia Journal 37-50.

11. Roy DK, Acharyya SK, Ray KK, Lahiri TC, Sen MK (1988) Nature of occurrence and depositional environment of the oceanic pelagic sediments associated with the ophiolite assemblage, South Andaman Island. Indian Mineralogy 42: 31-56. 